\title{
Conversion of Vegetable Waste to Lipid Feedstock for Biodiesel Production Aided with Nano Catalyst Using RSM Software
}

\author{
Murugan Sithan $^{1 *}$, Jayanthi Singaram² \\ ${ }^{1}$ Department of Civil Engineering, GCT, Coimbatore, Tamil Nadu, India \\ ${ }^{2}$ Government College of Engineering, Bodi, Theni, Tamil Nadu, India
}

Received: 7 July 2019

Accepted: 3 November 2019

\begin{abstract}
Progress in economy leads to increases in society's energy requirement. Fossil fuel is the major source of fulfilling energy requirements. Biodiesel is an alternative for liquid fossil fuel. In this study, biodiesel was produced from lipid obtained from vegetable waste using oleaginous yeast. The pretreated waste hydrolysate was used for the growth of oleaginous yeast, Lipomyces starkeyi which was able to yield a biomass concentration of $20 \mathrm{~g} / \mathrm{L}$. Obtained biomass was transesterified directly in the presence of Nanocatalysts calcium hydroxide and Aluminum oxide. The transesterification process was optimized by RSM software. The optimum ratio of Methanol to lipid was obtained as 6:1and catalyst concentration of $0.5 \%$. Optimum temperature for biodiesel production was obtained as $60^{\circ} \mathrm{C}$. Maximum amount of biodiesel obtained as $8 \mathrm{~g} / \mathrm{L}$ which is worked out to be $40 \%$ of the biomass used in this process. The oxidative stability of the obtained biodiesel was found out to be 1.84 years using biodiesel rancimat. Hence optimisation of process has yielded highly stable oil from microbial biomass grown from waste organic solids. The results of this study concluded that biodiesel can be obtained from biomass containing lipid by direct transesterification.
\end{abstract}

Keywords: lipid, transesterification, biodiesel, RSM, vegetable waste

\section{Introduction}

The world has been confronted with energetic and environmental calamities caused by burning of conventional fuels. The world's increasing demand for energy has led to an increase in fossils fuels consumption. However this source of energy is limited and is accompanied by environmental problems.

*e-mail: smurugan02@gmail.com
Biofuels are drawing increasing attention worldwide as substitutes for petroleum derived transportation fuels. The world energy organization annually addresses energy cost, energy security and global warming concerns associated with liquid fossil fuels. Biofuels are the fuels that derived from organic materials. They include wood, straw, sugarcane residue, animal waste, landfill gas, biodiesel, and ethanol. Ethanol derived from the fermentation of waste organic materials has been the popular Biofuel in the latter part of the $20^{\text {th }}$ century [1]. Again ethanol cannot be used alone and as of today blends of ethanol with petrol and diesel fuels 
are being used to curb the polluting effects of petrooil. Biodiesel, however is composed of long chains of esters that lack the risks associated with pure ethanol. Biodiesel is nothing but fatty acid methyl esters (FAME) obtained by transesterification of Tri-acyl Glycerol with alcohol in presence of a catalyst [2].

Biodiesel is a promising sustainable alternative and is expected to be a substitute for diesel derived from fossil fuels. Currently, biodiesel is produced via transesterification of triglycerides with alcohol using homogeneous catalysts. The availability and wide diversity of biomass resources have made them attractive and promising source of energy. Initially biodiesel was derived from edible oil and non-edible oil [3] by the process of transesterification. Then it was produced from algae [4]. Oleaginous organisms are able to store more intracellular fat in nitrogen limited conditions [5]. Cellulose and hemicelluloses present in biomass are potential source of energy for these organisms. Tri-acyl glycerol is available in vegetable oils, seed oils, plant oils and animal fats [6-8]. Following are the potential benefits which mark the world to seek attention towards biodiesel: biodiesel is renewable; it is biodegradable and non-toxic; it generates acceptable quality of exhaust gases [9]; it reduces the demand-supply gap and brings price stability; it reduces greenhouse gas emissions and contribute to less global warming; it increases the rural economy due to the excess production of various feed stock [10].

The complications existing with biodiesel production are its high cost, of which raw materials amount to approximately $75 \%$ of the total production cost. The consumption of large amounts of vegetable oils for biodiesel production could result in a shortage of edible oils, thus increasing the prices of food $[11,12]$. Hence researches has turned to produce biodiesel by utilizing non-edible oils [13], used waste oils [9, 14] and other sources. The present focus is towards the production of microbial oil (lipid) [15] from lignocellulosic biomass by using various oleaginous organisms and converting them to biodiesel $[16,17]$. Industrial waste like slaughter house wastewater [18], distillery wastewater [19] are also used for biodiesel production. Microorganism especially oleaginous species may accumulate more than $20 \%$ of lipid by mass fraction of biomass [20]. The amount of lipids that can be recovered from yeasts can vary according to the raw material used. This study focuses on utilizing vegetable waste as a source of energy and the oleaginous yeast Lipomyces starkeyi was utilized as a fat accumulating agent.

\section{Experimental}

In this study, vegetable waste was used (lignocellulosic biomass) as substrate and Lipomyces starkeyi was used as culture media. Vegetable waste was collected from hostels and canteen of the institution. The collected wastes were sorted based on the type of vegetable. These wastes were used as a substrate for the growth of oleaginous yeast. The microorganism will grow under aerobic conditions at $30^{\circ} \mathrm{C}$ in a Rotary Shaker at $150 \mathrm{rpm}$. Slant tube has been prepared with the same medium along with $20.0 \mathrm{~g} / 1$ nutrient agar.

\section{Pretreatment of Vegetable Waste}

Con. $\mathrm{H}_{2} \mathrm{SO}_{4}(1.5 \%)$ was added to both fresh and dry vegetable waste of weight $20 \mathrm{~g} / \mathrm{l}$ of distilled water. The mixture was placed in autoclave at a temperature of $121^{\circ} \mathrm{C}$ for 120 minutes and filtered the hydrolysate. The inoculation process was carried out inside the laminar airflow chamber. Then $70 \mathrm{ml}$ of Lipomyces Starkeyi was transferred into the autoclavable fermentor containing dry vegetable waste hydrolysate. Fermentation was carried out aerobically in $5 \mathrm{~L}$ fermentor, $10 \%(\mathrm{v} / \mathrm{v})$ inoculum was transferred aseptically, with a final working volume of $3.5 \mathrm{~L}$. The experiments conducted at $30^{\circ} \mathrm{C}$ with agitation rate of $120 \mathrm{rpm}$ under aerobic conditions. The fermentation was carried out at the optimized biomass production conditions. Fermentation was carried out at the $\mathrm{pH}$ of 8.0 , temperature $28-30^{\circ} \mathrm{C}$, aeration rate $2 \mathrm{~L} \mathrm{~min}^{-1}$ and stirring rate $120 \mathrm{rpm}$. The $\mathrm{pH}$ was automatically controlled at 8.0 by adding $5 \mathrm{M}$ $\mathrm{NaOH}$ and antifoam was added when necessary. The samples were taken at regular intervals to follow the cell growth and glucose concentration.

The efficiency of hydrolysis/depolymerisation experiments was analyzed by measuring the amount of glucose released from the cellulose rich waste materials. To analyze the glucose concentrations in UV spectrometer, the Phenol-Sulphuric acid method was employed. Initial glucose concentration was evaluated for vegetable waste hydrolysate at wavelength of $490 \mathrm{~nm}$. After the biomass growth, a decreasing sugar consumption tendency as well as cell growth performance. The initial sugar concentration was found out to be $400 \mathrm{~g} / \mathrm{l}$. Fermentation was carried out for six days. All the operating parameters were optimized based on batch study in the previous work.

The cultured sample was taken out from the autoclavable fermentor and biomass was extracted from the cultured sample using large volume centrifuge and it was centrifuged at 8000 RPM for 7 minutes. Then biomass collected after centrifuge was used for the lipid extraction. After biomass separation, the cell wall disruption was carried out by adding $0.1 \mathrm{~N} \mathrm{HCl}$ and grinded using mortar and pestle. Dry biomass was disrupted and homogenized in a pestle and mortar using $0.1 \mathrm{~N} \mathrm{HCl}$. Lipid was extracted from the Biomass with hexane: Isopropanol (5:3).

\section{Transesterification Process with Nano Catalyst}

Initially Calcium hydroxide and Aluminum oxide were taken which are available commercially. They were both ball milled at $150 \mathrm{rpm}$ for $2 \mathrm{hrs}$. Calcium hydroxide was doped with aluminum oxide using 
Size Distribution by Intensity

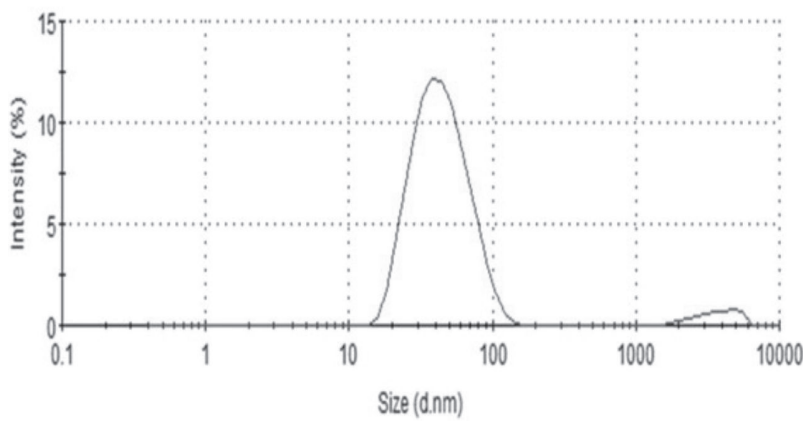

Fig. 1. Particle size of Nano catalyst.

sol-gel method then Calcined using muffle furnace at $550^{\circ} \mathrm{C}$ for $2 \mathrm{hrs}$. Then it was characterized by FTIR and particle size analyzer.

$1 \mathrm{ml}$ of lipid was added to $3-9 \mathrm{ml}$ of methanol and catalyst concentration range $0.5-1.5 \%$ was added. Then transesterification of lipid was carried at the temperature ranges between $50-70^{\circ} \mathrm{C}$ for 90 minutes and further $4 \mathrm{ml}$ of water is added to the sample and it was centrifuged at $800 \mathrm{rpm}$ for 10 minutes. The upper layer is FAME which is separated and analyzed using FTIR for confirmation of biodiesel.

Response surface modeling [21] predicts outcomes based on prior experiments and provides for several combinations and the degree of fit to each combination and it given as significant or insignificant. The parameters range for biodiesel production were set as methanol to lipids ratio - 3:1 to 9:1, catalyst concentration -0.5 to $1.5 \%$, temperature -50 to $70^{\circ} \mathrm{C}$ and reaction time of 90 mins. These parameters influence the production of biodiesel. These parameters were fed into the RSM software and it gave 17 combinations of parameters. The transesterification was carried out for those 17 combinations and the quantity of biodiesel obtained for each combination was recorded.

\section{Oxidative Stability Analysis}

The rancidity of the obtained biodiesel was checked for the oxidative stability under various temperatures. The instrument measured the oxidative stability of the biodiesel samples by analyzing the conductivity of vapors coming out from the heated oil at specific temperature. The instrument consists of two blocks each with options for different temperatures. $4 \mathrm{~g}$ of biodiesel were weighed and filled in cylindrical tubes. Then these tubes were kept on the heating blocks of the Biodiesel Rancimat. The air supply was set at $10 \mathrm{l} / \mathrm{h}$ and the blocks were set at $110^{\circ} \mathrm{C}$ and $120^{\circ} \mathrm{C}$. Inlets were connected with air supply to the tubes and outlet of exhaust was connected from the tubes to the conductivity cells. The air flow was started at the desired temperature was reached and continued till the induction time was reached and the values were plotted. After the induction time was reached, air supply was cut off. The conductivity vs time showing the induction time, oxidation peak and rancidity were calculated individually after the oxidation was completed. The second derivative of the conductivity vs time curve gave the induction time of a particular sample.

\section{Results and Discussion}

Initially Calcium hydroxide and Aluminum oxide were being taken commercially. They were both ball milled at $150 \mathrm{rpm}$ for $2 \mathrm{hrs}$. Calcium hydroxide was doped with aluminum oxide using sol-gel method then Calcined using muffle furnace at $550^{\circ} \mathrm{C}$ for $2 \mathrm{hrs}$. Then it was characterized by FTIR and particle size analyzer. The Nano catalyst was well within the Nano-range with a size of $53.36 \mathrm{~nm}$ with a surface to volume ratio of over 6 million which is shown in the Fig. 1.

The FT-IR spectrum of Calcium oxide - Aluminium hydroxide is shown in Fig. 2. The sharp and strong peak at $33540.23 \mathrm{~cm}^{-1}$ is due to the $\mathrm{O}-\mathrm{H}$ stretching vibration

Spectrum

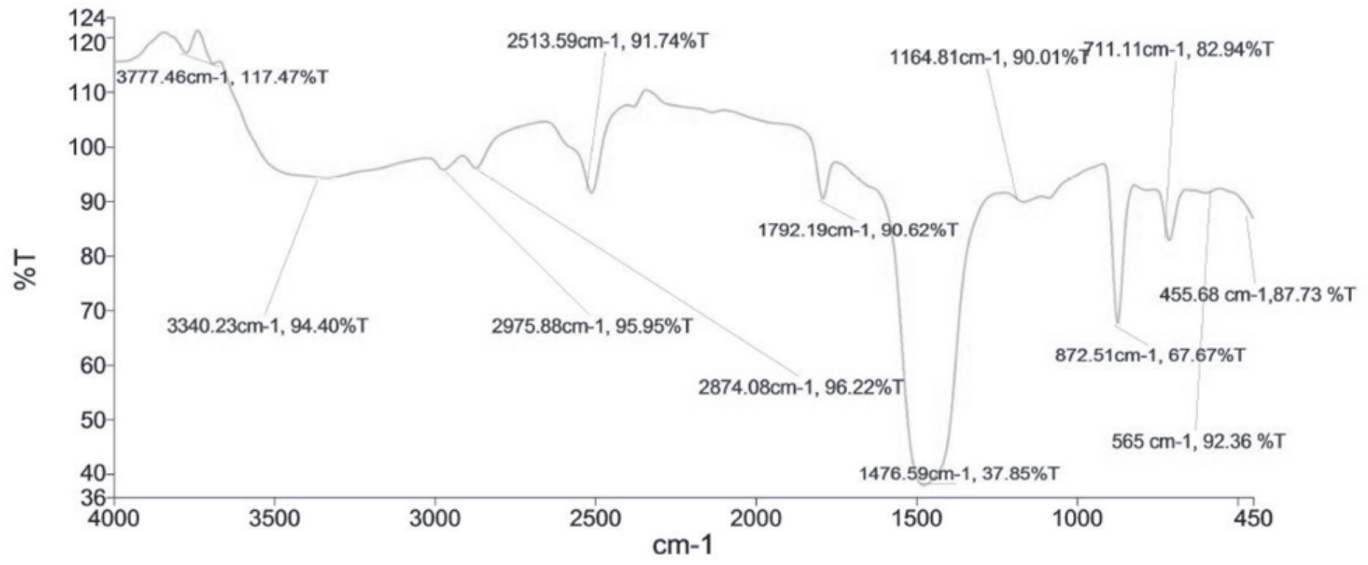

Fig. 2. FTIR result of Nano catalyst. 
Table 1. Batch Study Results of Transesterification Process.

\begin{tabular}{|c|c|c|c|c|c|c|}
\hline Std & Run & Block & $\begin{array}{l}\text { Factor } 1 \mathrm{~A} \text { : } \\
\text { molar ratio }\end{array}$ & $\begin{array}{l}\text { Factor } 2 \text { B: } \\
\text { catalyst (\%) }\end{array}$ & $\begin{array}{c}\text { Factor } 3 \mathrm{C} \text { : } \\
\text { temperature }\left({ }^{\circ} \mathrm{C}\right)\end{array}$ & $\begin{array}{c}\text { Response 1: } \\
\text { biodiesel }(\mathrm{g} / \mathrm{l})\end{array}$ \\
\hline 3 & 1 & Block 1 & 3 & 1.5 & 60 & 0.25 \\
\hline 5 & 10 & Block 1 & 3 & 1 & 50 & 0.325 \\
\hline 7 & 16 & Block 1 & 3 & 1 & 70 & 0.21 \\
\hline 1 & 17 & Block 1 & 3 & 0.5 & 60 & 0.2 \\
\hline 9 & 2 & Block 1 & 6 & 0.5 & 50 & 0.325 \\
\hline 11 & 3 & Block 1 & 6 & 0.5 & 70 & 0.2 \\
\hline 14 & 5 & Block 1 & 6 & 1 & 60 & 0.35 \\
\hline 16 & 6 & Block 1 & 6 & 1 & 60 & 0.34 \\
\hline 12 & 7 & Block 1 & 6 & 1.5 & 70 & 0.26 \\
\hline 17 & 11 & Block 1 & 6 & 1 & $60-$ & 0.305 \\
\hline 15 & 12 & Block 1 & 6 & 1 & 60 & 0.327 \\
\hline 13 & 14 & Block 1 & 6 & 1 & 60 & 0.31 \\
\hline 10 & 15 & Block 1 & 6 & 1.5 & 50 & 0.28 \\
\hline 6 & 4 & Block 1 & 9 & 1 & 50 & 0.28 \\
\hline 8 & 8 & Block 1 & 9 & 1 & 70 & 0.25 \\
\hline 4 & 9 & Block 1 & 9 & 1.5 & 60 & 0.22 \\
\hline 2 & 13 & Block 1 & 9 & 0.5 & 60 & 0.25 \\
\hline
\end{tabular}

in the $\mathrm{Al}(\mathrm{OH})_{3}$ structures. The $1476.59 \mathrm{~cm}^{-1}$ peak indicates the bent vibration of $\mathrm{H}-\mathrm{O}-\mathrm{H}$. The strong peak at $1164.81 \mathrm{~cm}^{-1}$ is assigned to the $\mathrm{Al}-\mathrm{OH}$ bending. The peak at 711.11 corresponding to Al-Ca-Al stretching is matched with the analysis reported earlier. From this analysis, it was confirmed that calcium was linked with Aluminium hydroxide complexes and precipitated.

\section{Optimization of Transesterification Process}

The 17 experiments from the batch study for biodiesel production were performed and the results were fed into the RSM software as shown in Table 1. After this step, the ANOVA analysis was carried out by the software and it gave the final result for the optimization in the form of a quadratic equation.

The optimization experiments for biodiesel were run as quadratic model. The ANOVA results were obtained and they are shown in Fig. 3 and Fig. 4. The P value was obtained as 0.0560 for biodiesel. The value is less than 0.50 which shows that the predicted model fits
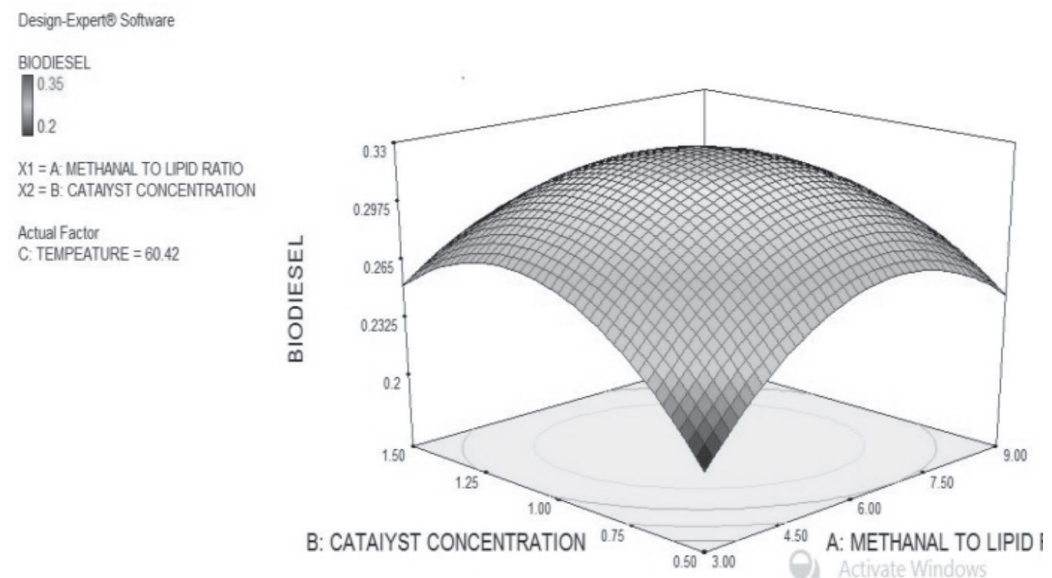

Fig. 3. Catalyst vs Methanol to lipid ratio. 


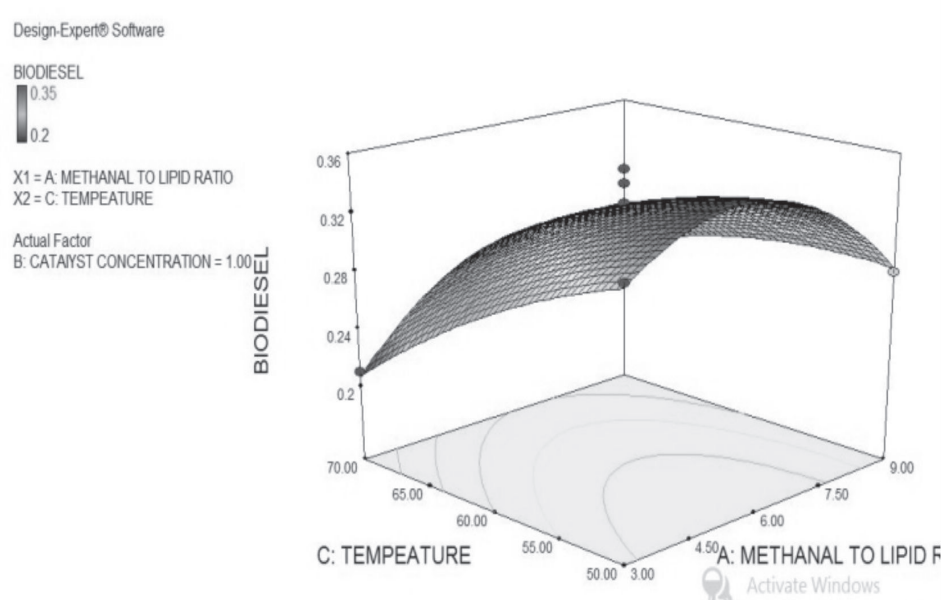

Fig. 4. Temperature vs Methanol to lipid ratio.

Table 2. Combinations given by RSM Software.

\begin{tabular}{|c|c|c|c|c|}
\hline S.No & Methanol to lipid ratio & Cataiyst concentration $(\%)$ & Tempeature $\left({ }^{\circ} \mathrm{C}\right)$ & Biodiesel (g/l) \\
\hline 1 & 4.84 & 0.91 & 50.63 & 0.350248 \\
\hline 2 & 5.47 & 0.96 & 51.41 & 0.350974 \\
\hline 3 & 5.08 & 1.01 & 50.62 & 0.350633 \\
\hline 4 & 4.94 & 0.87 & 50.05 & 0.351939 \\
\hline 5 & 6.11 & 0.86 & 50.64 & 0.351179 \\
\hline 6 & 5.73 & 0.97 & 51.32 & 0.350855 \\
\hline 7 & 5.46 & 0.89 & 51.17 & 0.351627 \\
\hline 8 & 5.53 & 0.91 & 51.49 & 0.35106 \\
\hline 9 & 5.79 & 0.93 & 51.87 & 0.350035 \\
\hline 10 & 5.79 & 0.96 & 50.69 & 0.35203 \\
\hline 11 & 6.08 & 0.8 & 50.5 & 0.350145 \\
\hline 12 & 5.17 & 0.91 & 50.6 & 0.352315 \\
\hline 13 & 5.8 & 0.82 & 50.14 & 0.352493 \\
\hline 14 & 5.59 & 1.02 & 50.01 & 0.351516 \\
\hline 15 & 5.26 & 0.8 & 50.36 & 0.350736 \\
\hline 16 & 5.52 & 0.92 & 51.54 & 0.350972 \\
\hline 17 & 6.11 & 0.85 & 51.16 & 0.350017 \\
\hline 18 & 5.3 & 0.85 & 50.73 & 0.351504 \\
\hline 19 & 5.41 & 0.96 & 51.17 & 0.351443 \\
\hline 20 & 5.64 & 0.79 & 50.55 & 0.350667 \\
\hline 21 & 5.49 & 0.97 & 51.74 & 0.350085 \\
\hline 22 & 5 & 0.96 & 50.46 & 0.351759 \\
\hline 23 & 5.88 & 0.83 & 50.68 & 0.35149 \\
\hline 24 & 6.3 & 0.88 & 50.15 & 0.351019 \\
\hline 25 & 5.08 & 0.99 & 51.02 & 0.350201 \\
\hline 26 & 5.23 & 0.98 & 50.25 & 0.352584 \\
\hline 27 & 5.92 & 0.87 & 50.24 & 0.353047 \\
\hline 28 & 5.25 & 0.93 & 51.38 & 0.350759 \\
\hline 29 & 5.65 & 0.97 & 51.51 & 0.350583 \\
\hline 30 & 5.29 & 1.04 & 50.28 & 0.350256 \\
\hline
\end{tabular}


Table 3. Optimum values of Transesterfication Process.

\begin{tabular}{|c|c|c|c|c|c|c|}
\hline S.No & Biomass $(\mathrm{mg} / \mathrm{l})$ & Lipid (mg/l) & Nano catalyst $(\%)$ & Reaction time $(\mathrm{min})$ & Temperature $\left({ }^{\circ} \mathrm{C}\right)$ & Biodiesel $(\%)$ \\
\hline 1 & 20.0 & 10.0 & 1.00 & 90 & 60 & 81.00 \\
\hline
\end{tabular}

with quadratic model. The lack of fit from the model is 0.2764 for biodiesel. Which is less than 0.50 which implies the results fit the model.

The central composite design allows for a 3 dimensional representation of optimum values with two variables. The result is a dome shaped graph showing the various ranges of values which can give the optimum results. The values closer to the maximum are represented at the top of the dome. Hence the corresponding values are optimum values for the selected variables. The various solutions for the different combinations of the experiments were given by the software and is shown in the Table 2 .

From Fig. 3, it is understood that when Methanol to Lipid ratio is increased Biodiesel quantity also increases up to ratio of 6.8 . When the ratio is increased beyond 6.8 amount of biodiesel production getting reduced. Hence Optimum Methonol ratio can be taken as 6.8. Similarly increase of Catalyst concentration cause for increase in Biodiesel production upto the concentration of 1.2 beyond which Biodiesel production getting reduced. It is clear that the optimum catalyst concentration can be taken as 1.2. Fig. 4 implies that when temperature was increased beyond Biodiesel quantity getting decreased. It was understood that optimum temperature can be taken as $50^{\circ} \mathrm{C}$.

The coefficients of determination $\left(\mathrm{R}^{2}\right)$ and adjusted- $\mathrm{R}^{2}$ were calculated to check the adequacy and fitness of the model. The $\mathrm{R}^{2}$ gives the proportion of total variation in the response predicted by the model.
The coefficient $\mathrm{R}^{2}$ was obtained as 0.9615 which indicates that only $3.85 \%$ of the total variations were not explained by the model. The adjusted- $\mathrm{R}^{2}$ was used to evaluate the model's adequacy and fitness. The adjusted- $\mathrm{R}^{2}$ value corrected the $\mathrm{R}^{2}$ value for the sample size and for the number of terms in the model. The value of 0.9121 was obtained for adjusted- $\mathrm{R}^{2}$ was also high and indicated a high correlation between the observed and the predicted values, which confirmed that the model was highly significant.

Final Equation in Terms of Coded Factors is given as BIODIESEL $=+0.32-4.000 \mathrm{E}-003 * \mathrm{~A}-0.015 * \mathrm{~B}$ $+0.013 * \mathrm{C}-2.500 \mathrm{E}-003 * \mathrm{~A} * \mathrm{~B}-2.000 \mathrm{E}-003 * \mathrm{~A} *$ $\mathrm{C}+7.250 \mathrm{E}-003 * \mathrm{~B} * \mathrm{C}-0.014 * \mathrm{~A}^{2}-0.02 * \mathrm{~B}^{2}+0.031$ $* \mathrm{C}^{2}$

Where $\mathrm{A}$ is molar ratio $\mathrm{B}$ is concentration of catalyst $(\%)$ and $\mathrm{C}$ is temperature $\left({ }^{\circ} \mathrm{C}\right)$. The optimum parameters are shown in Table 3.

The conversion of lipids into FAME was influenced by all three parameters by earlier studies. The reaction was found to be of pseudo-first-order with the forward reaction proceeding in the presence of excess methanol. Hence excess of methanol were used for the reaction and were recovered. The chemical purity of the lipid samples were also responsible for conversion, with additions of proteins and carbohydrates leading to hindrance of the process.

The reaction was found to be most effective when it was closer to the boiling point of methanol. At higher temperatures the alteration of catalyst structure caused

\section{Spectrum}

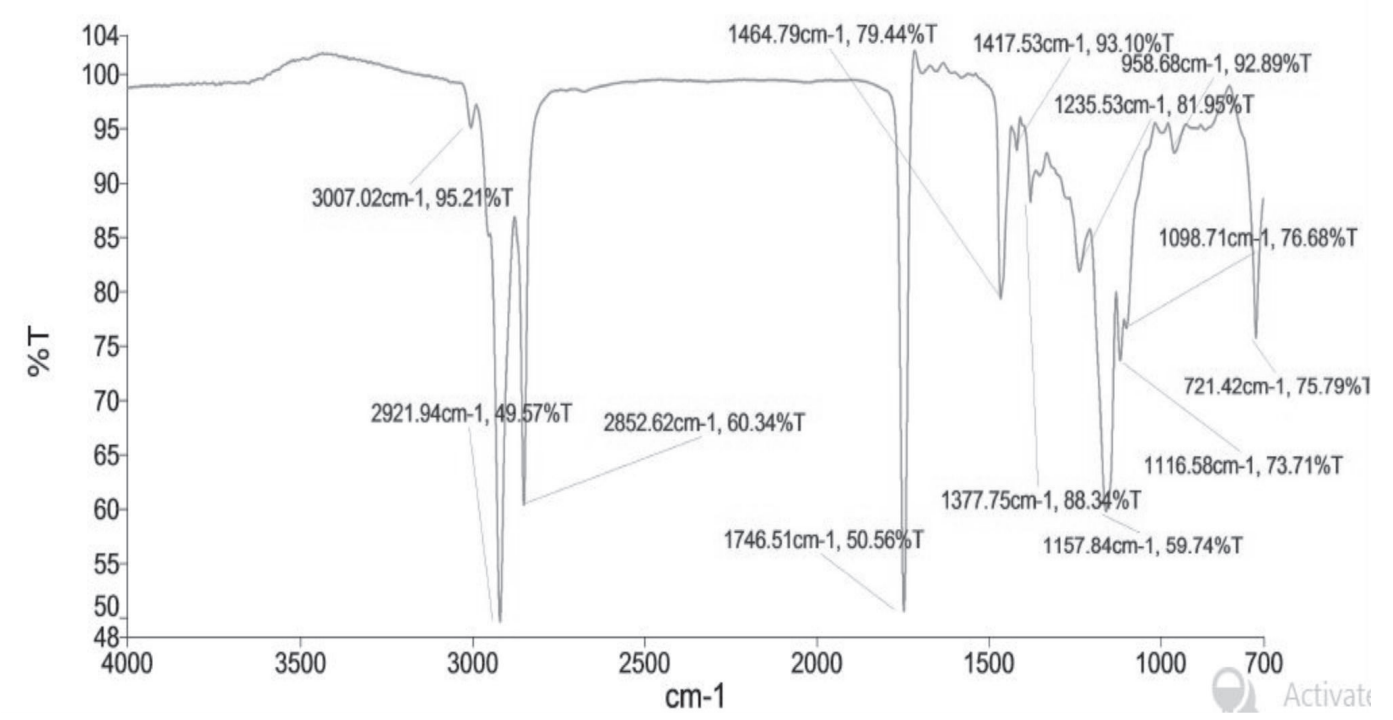

Fig. 5. FTIR results for FAME. 
a drop of FAME yield. The Higher catalyst concentrations $(>2 \%)$ have been implicated in soap formations and also inside product formations. Hence were used optimally.

The obtained FAME were analyzed using FTIR for determining the presence of characteristic functional groups that define lipids. The FTIR result was shown in the Fig. 5. The spectral signatures were analysed by in-built software called FLUKA. The peak at $2920 \mathrm{~cm}^{-1}$ corresponding to $\mathrm{C}=\mathrm{C}$ bonds which are characteristic of unsaturated bonds. The peak at $1746-1750 \mathrm{~cm}^{-1}$ indicates $\mathrm{C}=\mathrm{O}$ ester bonds. The peaks at $721-725 \mathrm{~cm}^{-1}$ which are characteristic of long chain hydrocarbons. The FLUKA library search returned esters such as Methyl linoleate (C18), Ethyl linoleate and Methyl Elaidate (C22), which all are classified as long-chain unsaturated fatty acid alkyl esters.

The oxidation stability is one of the major issues for implementing the use of biodiesel as an alternate fuel to petro diesel. Induction period for the FAME at $110^{\circ} \mathrm{C}$ was given as $22.32 \mathrm{hr}$. with the temperature correction of $0.9^{\circ} \mathrm{C}$. Induction period for the FAME at $120^{\circ} \mathrm{C}$ was given as $11.83 \mathrm{hr}$ with the temperature correction of $1.6^{\circ} \mathrm{C}$. The storage stability of the FAME was extrapolated using Arrhenius equation for thermal transfer. The stability time was obtained as 1.84 years at ambient temperature. This is on the higher end of stability than other oils. Hence microbial oil has been obtained which has higher thermal-oxidative and storage stability than conventional oils.

\section{Conclusions}

The pre-treated waste used for the growth of oleaginous yeast Lipomyces starkeyi was able to yield upto $60 \mathrm{~g}$ from 31 of waste hydrolysate. It amounted to a total of $20 \mathrm{~g} / 1$ of biomass from pre-treated waste. The lipid extraction was performed using hara and radin methods. The conversion of lipids to FAME was performed using Nano-catalysts prepared by co-precipitation of calcium and aluminium salts. The Nano catalysts were well within the Nanorange with a size of $53.36 \mathrm{~nm}(<100 \mathrm{~nm})$ with a surface to volume ratio of over 6 million. Hence the large surface area was instrumental in conversion of lipids into biodiesel in the reaction by bringing them closer. The optimisation of the reaction was performed using statistical design software using varying conditions and the optimum parameters were obtained as molar ratio of $6: 1$, catalyst concentration of $0.5 \%$ and temperature of $60^{\circ} \mathrm{C}$ corresponding to biodiesel yield of $8 \mathrm{~g} / \mathrm{l}$. The thermal-oxidative stability of the obtained biodiesel using rancimat was found out to be 1.84 years and was higher than other vegetable oils. Hence vegetable waste is a promising source for culturing oleaginous yeast which can be used as a source for producing biodiesel.

\section{Acknowledgements}

The research team conveys sincere gratitude to TEQIP III for having provided instrument and other facilities for conducting this research.

\section{Conflict of Interest}

The authors declare no conflict of interest with the study area.

\section{References}

1. SAHUAND S., PRAMANIK K. Evaluating Fungal Mixed Culture for Pretreatment of Cotton Gin Waste to Bioethanol by Enzymatic Hydrolysis and Fermentation Using Co-Culture, Pol. J. Environ. Stud., 26 (3), 12153, May 2017.

2. YUNUS KHAN T.M., BADRUDDIN I.A., ANKALGI R.F., BADARUDIN A., HUNGUND B.S. ANKALGI F.R., Biodiesel Production by Direct Transesterification Process via Sequential Use of Acid-Base Catalysis, Arabian Journal for Science and Engineering, 2018.

3. WU G., JIANG G., YANG Z., HUANG Z. Emission Characteristics for Waste Cooking Oil Biodiesel Blend in a Marine Diesel Propulsion Engine, Pol. J. Environ. Stud., 28 (4), 2911, Apr. 2019.

4. HUSSAIN F., BEI LU, XIN LAN, JING LYU, HONGKAI HUANG, WENGUANG ZHOU, SYED ZAHIR SHA, MUZAMIL SHA, FAISAL RAZA, MUHAMMAD SAEED, MUHAMMED SHUAIB Determining Indigenous Microalgae Species in Malakand Water Bodies for Potential Use as a Biofuel Production Source, Pol. J. Environ. Stud., 28 (2), 669, Dec. 2018.

5. BEOPOUlOS A., CESCUT J., HADDOUCHE R., URIBELARREA J.-L., MOLINA-JOUVE C., NICAUD J.-M. Yarrowia lipolytica as a model for bio-oil production, Progress in Lipid Research, 48 (6), 375, Nov. 2009.

6. BUASRI A., ACHANAI BUASRI, METHASIT LUKKANASIRI, RAVIPORN NERNRIMNONG, SURACHAI TONSEEYA, KANOKPHOL ROCHANAKIT, WASUPON WONGVITVICHOT, URAIPORN MASA-ARD, VORRADA LORYUENYONG Rapid transesterification of Jatropha curcas oil to biodiesel using novel catalyst with a microwave heating system, Korean Journal of Chemical Engineering, 33 (12), 3388, 2016.

7. HAN X., XIAOXIANG HAN, WEI YAN, CHINTE HUNG, YANFEI HE, PEI-HAO WU, LI-LI LIU, SHING-JONG HUANG AND SHANG-BIN LIU Transesterification of soybean oil to biodiesel by tinbased Brønsted-Lewis acidic ionic liquid catalysts, Korean Journal of Chemical Engineering, 33 (7), 2063, 2016.

8. MOSER B.R. Biodiesel production, properties, and feedstocks, In Vitro Cellular \& Developmental Biology Plant, 45 (3), 229, 2009.

9. IBETO C., UGWU C. Exhaust Emissions from Engines Fuelled with Petrol, Diesel and their Blends with Biodiesel Produced from Waste Cooking Oil, Pol. J. Environ. Stud., 
28 (5), 3197, May 2019.

10. QIUL J., FAN X., ZOU H. Development of biodiesel from inedible feedstock through various production processes. Review, Chemistry and Technology of Fuels and Oils, 47 (2), 102, 2011.

11. HUANG C., FANG CHEN X., XIONG L., DE CHEN X., LONG MA L., CHEN Y. Single cell oil production from low-cost substrates: The possibility and potential of its industrialization, Biotechnology Advances, 31 (2), 129, 2013.

12. SUBHASH G.V., MOHAN S.V. Sustainable biodiesel production through bioconversion of lignocellulosic wastewater by oleaginous fungi, Biomass Conversion and Biorefinery, 5 (2), 215, 2015.

13. OBLIGADO A.B., DEMAFELIS R.B., MATANGUIHAN A.E.D., VILLANCIO V.T., MAGADIA R.V., MANAIG L.M.A. Carbon emission inventory of a commercial-scale Jatropha (Jatropha curcas L.) biodiesel processing plant., Journal of Environmental Science and Management, 20 (Special Issue 1) 20, 2017.

14. QURESHI M.W.G., KHAN Z.M., HUSSAIN M., AHMED F., SHOAIB M., QASIM M. Experimental Evaluation of a Diesel Engine for Combustion, Performance and Exhaust Emissions with Fuel Blends Derived from a Mixture of Fish Waste Oil and Waste Cooking Oil Biodiesel, Pol. J. Environ. Stud., 28 (4), 2793, Apr. 2019.

15. LI Q., DU W., LIU D., Perspectives of microbial oils for biodiesel production, Applied Microbiology and Biotechnology, 80 (5), 749, Oct. 2008.

16. MIRZA S., SIDDIQUE S., QAMER H.M., DOGGAR
M.G. Optimization of lipid production potential of oleaginous yeast by response surface methodology cultivated in agro-industrial waste, International Journal of Environmental Science and Technology, no. 0123456789, $1,2018$.

17. LU W., ALAM M.A., PAN Y., NOCK W.J., WANG Z., YUAN Z. Optimization of algal lipid extraction by mixture of ethyl acetate and ethanol via response surface methodology for biodiesel production, Korean Journal of Chemical Engineering, 33 (9), 2575, 2016.

18. ASOKAN T., SINGARAM J., SUNDARAM P.V. Production of biodiesel feedstock - microbial lipid from slaughterhouse wastewater, International Journal of Environment and Sustainable Development, 17 (2-3), 113, Jan. 2018.

19. ANBARASAN T., JAYANTHI S., RAGINA Y. Investigation on Synthesis of Biodiesel from Distillery Spent Wash using Oleaginous Yeast Metschnikowia Pulcherrima, Materials Today: Proceedings, 5 (11), Part 2, 23293, Jan. 2018.

20. HEGEL P.E., CAMY S., DESTRAC P., CONDORET J.S. Influence of pretreatments for extraction of lipids from yeast by using supercritical carbon dioxide and ethanol as cosolvent, Journal of Supercritical Fluids, 58 (1), 68, 2011.

21. SUKRI S.S.M., RAHMAN R.A., YAAKOB H. Optimization of Alkaline Pretreatment Conditions of Oil Palm Fronds in Improving the Lignocelluloses Contents for Reducing Sugar Production, Romanian Biotechnological Letters, 19 (1), 13, 2014. 